\title{
Assessment of Heavy Metals and Organics in Municipal Solid Waste Leachates from Landfills with Different Ages in Jordan
}

\author{
Malyuba Abu-Daabes $^{1 *}$, Hani Abu Qdais ${ }^{2}$, Hatem Alsyouri ${ }^{3}$ \\ ${ }^{1}$ Pharmaceutical-Chemical Engineering Department, German-Jordanian University, Amman, Jordan; ${ }^{2}$ Department of Civil Engineer- \\ ing, Jordan University of Science and Technology, Irbid, Jordan; ${ }^{3}$ Department of Chemical Engineering, The University of Jordan, \\ Amman, Jordan. \\ Email: *malyuba.abudaabes@gju.edu.jo,hqdais@just.edu.jo, Alsyouri@ju.edu.jo
}

Received February $11^{\text {th }}, 2013$; revised March $15^{\text {th }}, 2013$; accepted April $14^{\text {th }}, 2013$

Copyright (C) 2013 Malyuba Abu-Daabes et al. This is an open access article distributed under the Creative Commons Attribution License, which permits unrestricted use, distribution, and reproduction in any medium, provided the original work is properly cited.

\begin{abstract}
A comprehensive assessment of heavy metals and organic content was performed for leachates produced from a number of old and new landfills in Jordan over 9 month in efforts to set a framework for treatment regulations. All leachates were basic $(\mathrm{pH}=7-9)$ and have high electric conductivity and high organic contents (COD = 3000 - 500,000 mg/L, $\mathrm{TOC}=500-21,000 \mathrm{mg} / \mathrm{L}$ ). The organic content was inversely proportional to the age of landfill. Heavy metals analysis showed no significant threat of $\mathrm{Co}, \mathrm{Zn}, \mathrm{Pb}$ and $\mathrm{Al}$ in any site. Meanwhile, the concentrations of $\mathrm{Cr}, \mathrm{Mn}, \mathrm{Ni}, \mathrm{Cd}$ and $\mathrm{As}$ were high, exceeding local and international standard limits. Typical physical, chemical and biological treatments can be employed to upgrade the leachates of the active Ghabawi and Akaider sites. Whereas for the high organic strength of Russeifeh, an adsorption treatment by activated carbon is recommended.
\end{abstract}

Keywords: Landfill; Leachate; Heavy Metals; Organic; Jordan; Ghabawi; Akaider; Russeifah

\section{Introduction}

Several countries rely on landfilling as a primary solid waste disposal method which is widely known to yield a wastewater product called leachate. The leachate is formed as a result of multiple chemical and biological reactions of solid waste within the landfill and can be a major contamination problem if not controlled properly. Organic and inorganic compounds leach out from the solid matrix into a liquid carrier (normally water) forming a wastewater with extremely high contamination strength exceeding that of municipal and industrial wastewaters [1]. Landfill leachate can cause severe health and environmental impacts represented by toxicity, soil, groundwater and surface water contamination [2-4] which implies the necessity for leachate treatment before its ultimate disposal.

Several countries around the world are enforcing more stringent regulations regarding the disposal of landfill leachate [5]. Jordan is a Middle-Eastern country that relies exclusively on landfilling. Currently, there are 21 operating landfills in Jordan generating large amounts of

\footnotetext{
${ }^{*}$ Corresponding author.
}

leachate, unfortunately, with insufficient enforcement of leachate disposal regulations, although the country is very scarce in water supply. One reason is the lack of comprehensive information on leachate characteristics and their threat on the water resources in this arid area. Therefore, understanding and monitoring the composition and quantity of landfill leachates are essential in selecting a satisfactory treatment method for pollutants removal and protecting possible groundwater from contamination [6]. In general, the goal of leachate treatment is to reduce the concentration of pollutants or to stabilize them in order to comply with regulations and standards of discharge into the environment. Alternatively, leachates can be upgraded to levels treatable by conventional municipal wastewater treatment facilities.

Leachates are generally studied for their organic contents, in terms of Chemical Oxygen Demand (COD) and Total Organic Carbon (TOC), salts content, and heavy metals concentrations [7]. Some researchers have quantified the leachate contamination potential using a leachate pollution index (LPI) [1]. In an attempt to make this index more representative and universal, the overall LPI was divided into three sub-indices summed linearly using 
the coefficients: organic components (23.2\%), inorganic components $(25.7 \%)$ and heavy metals $(51.1 \%)$. The high weighting factor of heavy metals emphasizes their obvious potential threat. For example, Abu Rukah and El-Aloosy [8] found that several metal ions migrate from Akaider landfill in northern Jordan and constitute a serious threat to aquifers surrounding it.

The nature of leachate varies significantly among landfills depending on waste composition, climatic conditions (such as rainfall rate), landfill age and landfilling technology [9-12]. Al-Yaqout and Hamoda [13] evaluated leachate in the arid climate of Kuwait from active and closed landfills. The leachate produced from both types of landfills was found to be severely contaminated with organics, salts and heavy metals. By comparing Kuwaiti landfills leachates with those produced in USA, Italy and Germany, the strength of leachate in Kuwait was found to be lower because of the dilution effect caused by rising water table. The researchers also concluded that the leachate characteristics do not show a definite trend with age. Kulikowska and Klimiuk [14] studied the influence of municipal landfill age on temporal changes in municipal leachate quality. The principal pollutants in leachate were organics and ammonia. They found that the COD of leachate decreased with the age of landfill; COD decreased from 1800 to $610 \mathrm{mg} / \mathrm{L}$ within four years of landfill exploitation. This was a result of degradation and volatilization of aromatic hydrocarbons, the most organic compounds reported in landfill leachate [15], with the age of the landfill.

To date, there is no comprehensive study on leachate characteristics from the Jordanian landfills, which hinders the enforcement of control systems for the protection of scarce water resources. Excluding the Ghabawi landfill that serves the Capital city Amman, all Jordanian landfills are considered as unsanitary because they lack management systems for the produced leachate and biogas. The main objective of this study is to perform a full assessment (based on heavy metals and organic content) for leachates produced from major landfills in Jordan with different ages and management systems. Three landfills will be covered in the study, namely: 1) Russiefeh site-Zarqa (old-closed); 2) Akaider site-Irbid (oldactive); and 3) Ghabawi site-Amman (new-active). Worldwide, the results of this study will be useful for future comparison with other countries. Locally, this study will provide guidelines for selecting the appropriate leachate treatment method for each one of these landfills.

\section{Material and Methods}

\subsection{Site Selection}

Three landfills were selected in this study based on their age, activity and control method. General conditions of the landfills are summarized in Table 1. The old-active Akaider landfill is located $27 \mathrm{~km}$ to the east of the city of Irbid, and has been used since 1981. It is considered as the principal landfill for northern Jordanian cities like Irbid and Jerash. In this site, municipal solid waste is landfilled, while liquid industrial waste is stored in evaporation ponds. The water-table below the surface at this site is 300 to $450 \mathrm{~m}$ [16]. This site does not have a bottom liner or a leachate collection system, thus, we considered it an uncontrolled landfill.

Russeifah landfill (old-closed) was opened in 1987 and had been the largest Jordanian landfill until the Ghabawi site was established in 2003. Russeifah landfill is located east of Amman (the capital of Jordan) and served 2.5 million capita living mainly in Amman, Zarqa and Russeifah [17]. The Russeifah landfill was used to receive 2100 tons/day of waste including $75 \%$ of the generated domestic solid waste as well as medical and industrial wastes [18]. The landfill was uncontrolled and caused serious environmental problems. The depth of the watertable in the landfill does not exceed $22 \mathrm{~m}$ with no barrier or geotextile layers to prevent the percolation of leachates $[17,19]$. This landfill is currently closed.

A new landfill, Ghabawi, was established in 2003 and is considered to be the only sanitary landfill in Jordan with a lining and a leachate collection system. The landfill is located $15 \mathrm{~km}$ south of Amman. The Ghabawi

Table 1. General condition of the selected Jordanian landfills.

\begin{tabular}{|c|c|c|c|}
\hline Landfill & Russeifah & Akaider & Ghabawi \\
\hline Status & Old-closed & Old-active & New-active \\
\hline Period of landfilling & 30 years & 25 years & 8 years \\
\hline Landfilling area & $65,000 \mathrm{~m}^{2}$ & $800,000 \mathrm{~m}^{2}$ & $2,000,000 \mathrm{~m}^{2}$ \\
\hline $\begin{array}{l}\text { Landfilling area } \\
\text { occupied }\end{array}$ & - & $200,000 \mathrm{~m}^{2}$ & $150,000 \mathrm{~m}^{2}$ \\
\hline Waste type & Municipal & Municipal & Municipal \\
\hline Topography & Mild slope & Mild slope & Mild Slope \\
\hline Soil type & Phosphogypsum & $\begin{array}{l}\text { Silty with lime } \\
\text { stone }\end{array}$ & Silty \\
\hline $\begin{array}{l}\text { Average daily } \\
\text { tonnage }\end{array}$ & - & 1000 & 2400 \\
\hline Bottom liner & No & No & Yes \\
\hline Cover soil thicness & $0.3 \mathrm{~m}$ & $0.5 \mathrm{~m}$ & $0.7 \mathrm{~m}$ \\
\hline Leachate treament & No & No & No \\
\hline $\begin{array}{c}\text { Volume of leachate } \\
\text { dicharged }\end{array}$ & $\mathrm{NA}^{*}$ & NA & NA \\
\hline
\end{tabular}

*NA: not available. 
landfill receives 2300 tons/day. The depth to groundwater in Ghabawi area is in the range of $80 \mathrm{~m}$ to more than $200 \mathrm{~m}$ [17]. Figure 1 shows the location of the landfills.

\subsection{Leachate Sampling}

Samples were continuously collected at the beginning of each month for the period October 2009 to June 2010. The samples were preserved in the refrigerator at $5^{\circ} \mathrm{C}$ upon arrival. A bottle of each sample $(250 \mathrm{~mL})$ was also preserved in the freezer at $-17^{\circ} \mathrm{C}$ in case of a need for data reproduction. The $\mathrm{EC}$ and $\mathrm{pH}$ of each leachate sample was measured upon arrival using Hach sensION5 Conductivity Meter and Hach sensION1 Portable $\mathrm{pH}$ Meter, USA, respectively. The leachate samples were collected at the drainage point from the landfill body into the evaporation pond. At each time of sampling, a composite sample that consisted of several grab samples was prepared and delivered to the laboratory.

\subsection{Leachate Organic Contents}

The concentration of organic content in leachate samples was estimated by measuring both COD and TOC. COD and TOC measurements were performed using Hach DRB-200 reactor, USA. COD digestive reagent vials supplied by Hach , USA, in the range $0-1500 \mathrm{mg} / \mathrm{L}$, and $1-15,000 \mathrm{mg} / \mathrm{L}$ were used with HACH DRB-200 reactor and Hach DR/890 Colorimeter. The sample was heated for two hours with potassium dichromate, a strong oxidizing agent. Oxidizable organic compounds react, reducing the dichromate ion $\left(\mathrm{Cr}_{2} \mathrm{O}_{7}^{2-}\right)$ to green chromic ion $\left(\mathrm{Cr}^{3+}\right)$. The amount of $\mathrm{Cr}^{3+}$ produced is determined

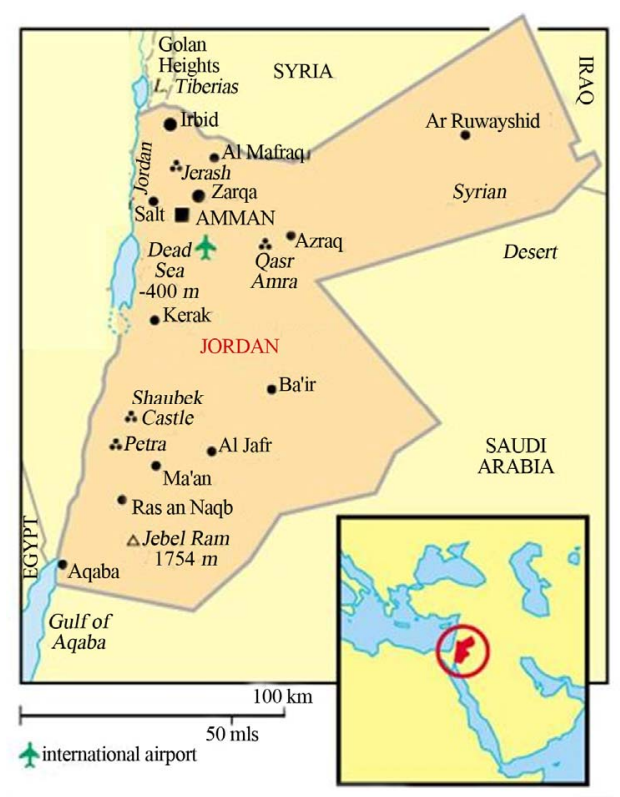

Figure 1. Distribution of selected landfills. using Hach DR/890 Colorimeter. The COD reagent also contains silver and mercury ions. Silver is a catalyst, and mercury is used to complex the chloride interference. The $\mathrm{mg} / \mathrm{L}$ COD results are defined as the $\mathrm{mg}$ of $\mathrm{O}_{2}$ consumed per liter of sample under the Reactor Digestion Method approved for reporting wastewater. TOC acid digestion vials in the range $100-700 \mathrm{mg} / \mathrm{L}$ were also supplied by Hach, USA. TOC was measured by first sparging the sample under slightly acidic conditions $(\mathrm{pH}$ 2 ) to remove the inorganic carbon. The organic carbon was digested by persulfate and acid to form $\mathrm{CO}_{2}$ which was absorbed into a $\mathrm{pH}$ indicator reagent to form carbonic acid. The amount of color change of the indicator solution is related to the original amount of carbon present in the sample.

\subsection{Heavy Metals Analysis}

Leachate samples were digested as follows: $50 \mathrm{~mL}$ of well-mixed sample was transferred to a beaker and heated, without boiling, using a hotplate until the volume was reduced to $15-20 \mathrm{~mL}$. Concentrated nitric acid (15 $\mathrm{mL}$ ) was added and the sample was heated for $30 \mathrm{~min}$ utes. Afterwards, $15 \mathrm{~mL}$ of concentrated hydrochloric acid was added and the sample was further heated for 30 minutes. The solution was then allowed to cool to room temperature and then filtered to remove any insoluble material. The digested sample was then transferred quantitatively with deionized water to a $100 \mathrm{~mL}$ volumetric flask and diluted to volume. Samples were digested and analyzed in duplicates. The samples were analyzed for their heavy metals content using the Inductive Coupled Plasma Technique (ICP, Perkin-Elmer, Optima DV2000, USA). The analysis included the following metals $\mathrm{Ni}, \mathrm{Co}$, $\mathrm{Cr}, \mathrm{Zn}, \mathrm{Pb}, \mathrm{Mn}, \mathrm{Al}, \mathrm{Cd}$, and $\mathrm{Cu}$. Arsenic (As) was analyzed using Atomic Absorption technique with hydridegeneration system (Shimadzu AA-6300, Japan).

\subsection{Statistical Analysis}

One way ANOVAs were performed in order to determine possible statistically significant differences among all parameters analyzed in leachates for every month. Data in the Figures 2-4 represent the mean and standard errors. The absence of a bar for a particular month indicates that no leachate was collected from that site or that the measured value was not detected in the collected leachate. For these figures the confidence level is $95 \%$ ( $\alpha$ $=0.05$ ).

\section{Results and Discussion}

Jordanian Municipal Solid Waste (MSW) is typically composed of $56 \%$ organic, $17 \%$ paper/card, $13 \%$ plastic, $5 \%$ metal, $7 \%$ glass and $2 \%$ miscellaneous as leather and 
wood [18]. Chemical characteristics of leachate samples collected from the three selected landfills in this study are presented in Table 2. The results were compared to previously reported studies on Akaider and Russiefeh landfills [20] as well as to results from other Asian countries [21].

\subsection{Organic Contents}

The biological decomposition period of the deposited wastes develops from a relatively short initial period to a longer decomposition period as the landfill becomes older. This will result in two main phases: acid phase and the stable methanogenic phase $[22,23]$. Organic content of the leachate samples was estimated by measuring both COD and TOC. The COD is usually used to quantify the total amount of contaminants (organic and inorganic) present in the leachate, where both types are subject to oxidation. TOC, on the other hand, represents the amount of carbon bound in an organic compound and is independent of the oxidation state of the organic matter. Therefore, TOC is a more direct expression of total or-

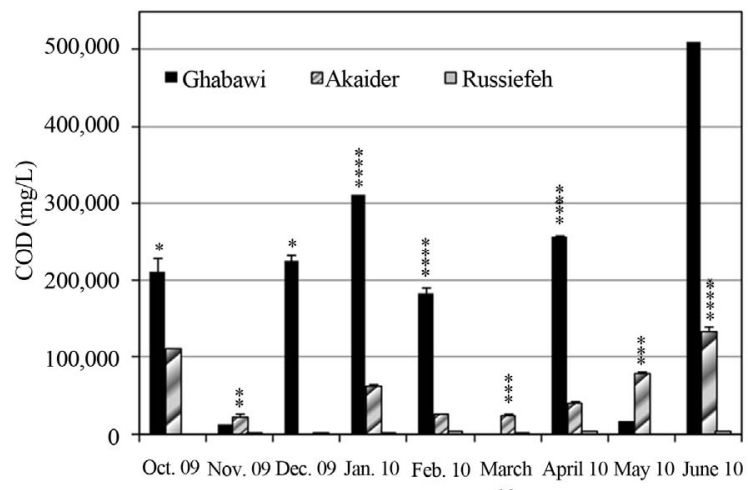

10

Figure 2. COD of Jordanian landfill leachates (limit 150 $\mathrm{mg} / \mathrm{L}) .{ }^{*} \mathrm{p}<0.05,{ }^{* * *} \mathrm{p}<0.01,{ }^{* * * *} \mathrm{p}<0.001,{ }^{* * * * *} \mathrm{p}<0.0001(\alpha=$ 0.05).

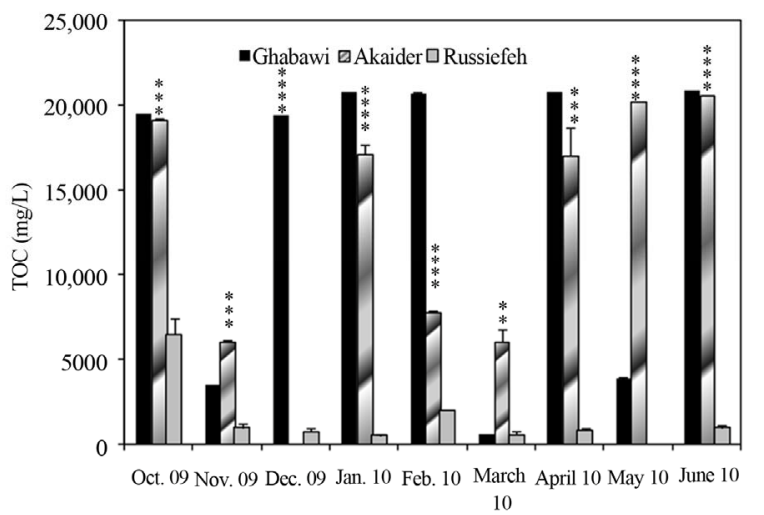

Figure 3. TOC of Jordanian landfill leachates. ${ }^{*} \mathrm{p}<\mathbf{0 . 0 5},{ }^{* *} \mathrm{p}$ $<0.01,{ }^{* * *} \mathrm{p}<0.001,{ }^{* * * *} \mathrm{p}<0.0001(\alpha=0.05)$. ganic content than COD.

Variations of COD and TOC of the leachates over the entire period of study are summarized in Figures 2 and $\mathbf{3}$. The results show that COD values decrease with the age of the landfill whether the site is controlled or uncontrolled. The highest COD value was for the new-controlled Ghabawi site indicating that it has very high levels of complex organic content. Likewise, the lowest COD corresponds to the closed-uncontrolled site of Russiefeh. The results are in agreement with values reported in other countries for active-controlled and uncontrolled landfills as shown in Table 2 [21]. Typically, the concentrations of organic and heavy metals contaminants change with the age of leachate [23]. COD values for Ghabawi and Akaider sites are both in the acetic phase $(6000-60,000 \mathrm{mg} / \mathrm{L})$ while Russaifa is in the methanogenic phase $(500-4500 \mathrm{mg} / \mathrm{L})[24,25]$.

Comparing the measured COD values to the limit set by the Jordanian industrial wastewater standard, which is $150 \mathrm{mg} / \mathrm{L}$, shows that leachates from all three lanfills are beyond this limit (Figure 2). Furthermore, Russiefeh landfill leachate shows significant decrease in its COD values from $229,932 \mathrm{mg} / \mathrm{L}$ [20] to $4000 \mathrm{mg} / \mathrm{L}$ (this study) in the period 1996 to 2010 as shown in Table 2. Therefore, most of the complex organic contents have degraded into much smaller compounds. On the other hand, COD values in Akaider landfill has increased significantly from $1237 \mathrm{mg} / \mathrm{L}$ in 1996 to a mean value of $64,109 \mathrm{mg} / \mathrm{L}$ in 2010 indicating a huge increase in the amount of wastes disposed within this period. The high value of COD in the active landfills resulted also from the low rainfall rate in the last ten years as well as the high evaporation rates due to high mean temperatures in summer seasons in Jordan.

A different behaviour of TOC values was observed for the tested landfills. The active sites (Ghabawi and Akadier) have comparable average TOC values of 16,000 and $14,000 \mathrm{mg} / \mathrm{L}$, respectively, higher than that of Russiefeh site $(959 \mathrm{mg} / \mathrm{L})$, as shown in Figure 3. This result is expected since both sites are still active and have continuous dumping of different organic wastes. TOC concentration increased for Akaider landfill from 168 $\mathrm{mg} / \mathrm{L}$ in 1996 to $14,286 \mathrm{mg} / \mathrm{L}$ in 2010 . On the other hand, waste aging decreased TOC from $3592 \mathrm{mg} / \mathrm{L}$ in 1996 to $959 \mathrm{mg} / \mathrm{L}$ in 2010 for the closed Russiefeh site, as shown in Table 2.

Using the ratio of TOC/COD, we can evaluate the degradation rate of the organic content. For the studied landfill sites, TOC/COD increased as the disposal time extended. Table 2 shows that the average TOC/COD ratio for the new Ghabawi active site $(0.12)$ is less than that for the old sites of Akaider and Russiefeh $(0.25$ and 0.24 , respectively). It has been reported that the strongest 


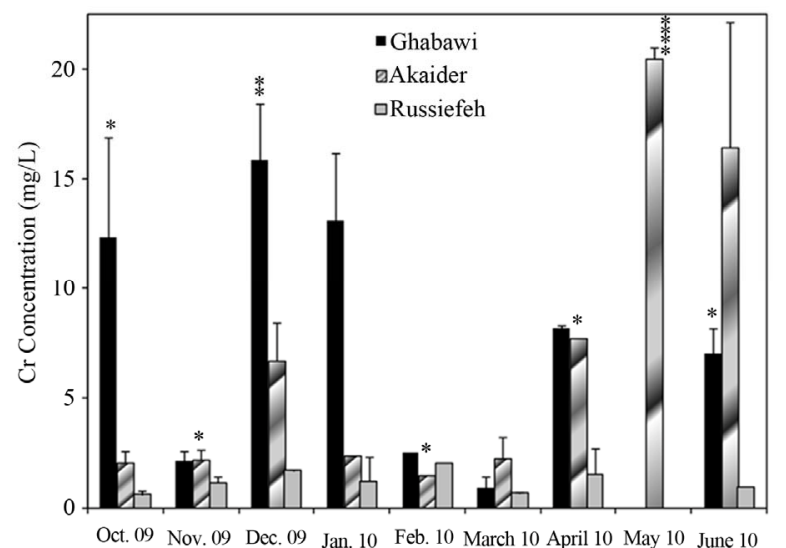

(a)

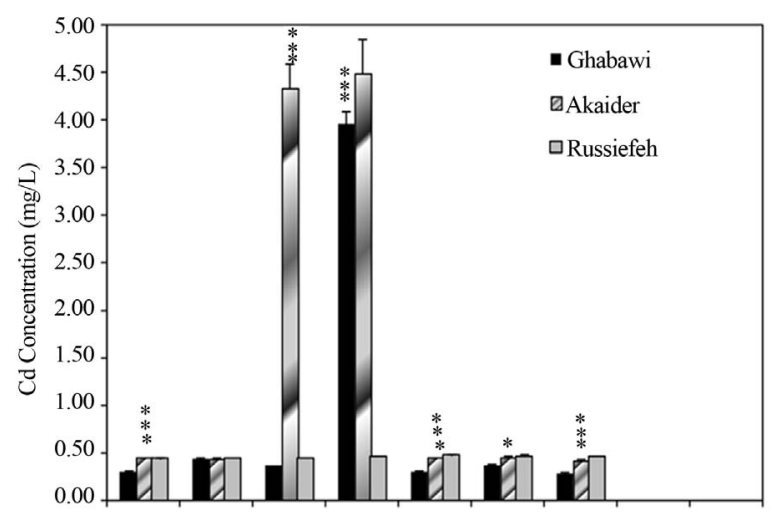

Oct. 09 Nov. 09 Dec. 09 Jan. 10 Feb. 10 March April 10 May 10 June 10

(c)

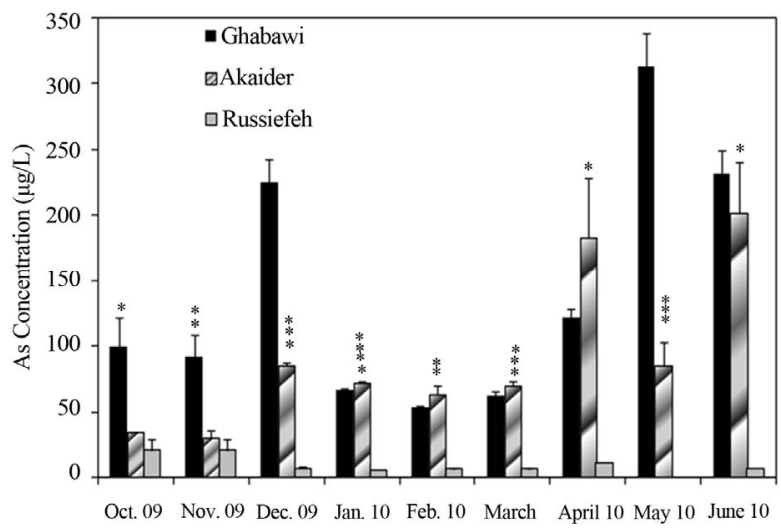

(e)

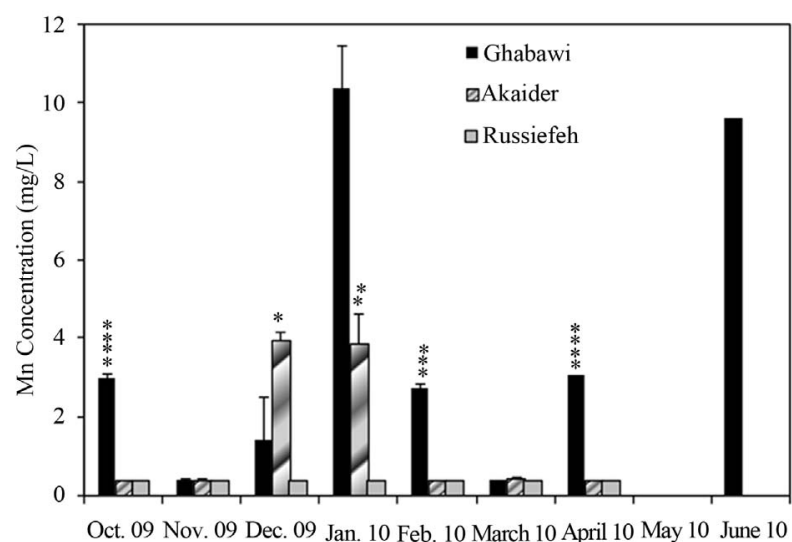

(b)

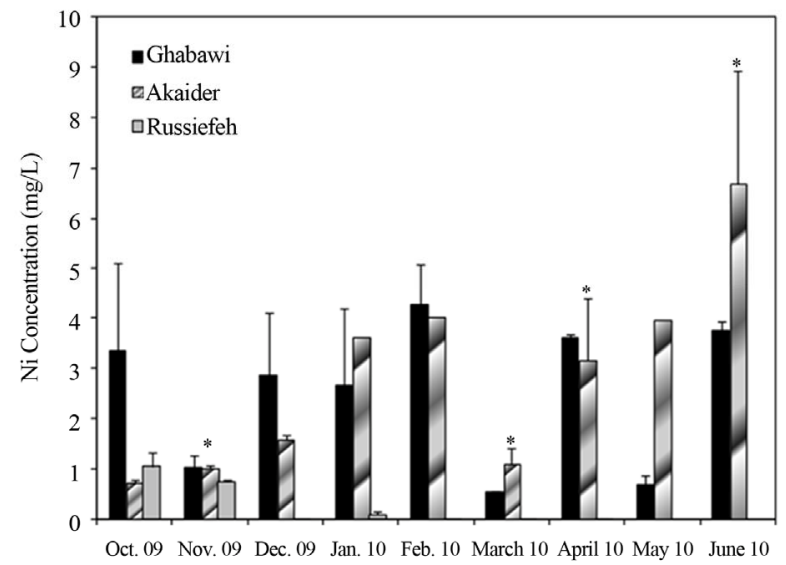

(d)

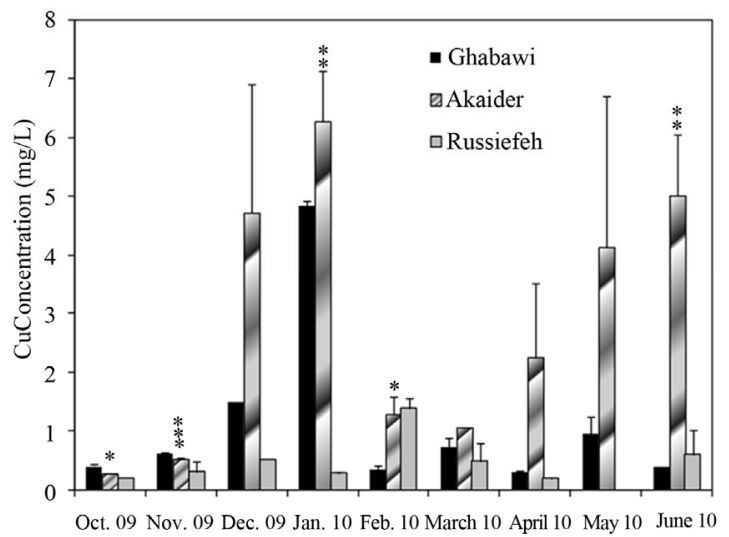

(f)

Figure 4. Concentration variation of: (a) Cr (JIEC limit $0.1 \mathrm{mg} / \mathrm{L}$, EPA limit $0.05 \mathrm{mg} / \mathrm{L}$ ); (b) Mn (JIEC limit $0.2 \mathrm{mg} / \mathrm{L}$ ), (c) Cd

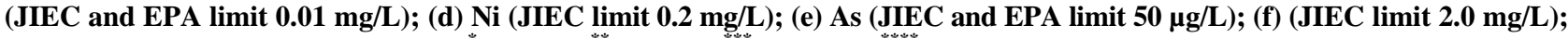
$\mathrm{Cu}$ in the leachates of three landfills. ${ }^{*} \mathrm{p}<0.05,{ }^{* *} \mathrm{p}<0.01,{ }^{* * *} \mathrm{p}<0.001,{ }^{* * * *} \mathrm{p}<0.0001(\alpha=0.05)$.

decrease of the readily organic compounds occur in the initial periods of landfilling [11] while the hardly degradable inorganic portion of COD is not significantly affected. This will result in a decrease in the TOC/COD ratio of the younger landfill compared to the old ones.
The behaviour of TOC/COD ratio with landfill age in this study is in agreement with that reported in the literature [26]. The difference in COD and TOC values between the sites is due to age of landfill, types of waste, climate conditions, topography, landfill cover, degree of 
Waste Leachates from Landfills with Different Ages in Jordan

Table 2. Chemical characteristics of leachate samples from different types of landfills.

\begin{tabular}{|c|c|c|c|c|c|c|c|c|c|}
\hline \multirow[t]{2}{*}{ Parameter } & \multicolumn{2}{|c|}{$\begin{array}{c}\text { Active controlled } \\
\text { landfill (Ghabawi) } \\
\text { this study }\end{array}$} & \multicolumn{2}{|c|}{$\begin{array}{l}\text { Active uncontrolled } \\
\text { landfill (Akaider) } \\
\text { this study }\end{array}$} & \multicolumn{2}{|c|}{$\begin{array}{l}\text { Closed uncontrolled } \\
\text { landfill (Russiefeh) } \\
\text { this study }\end{array}$} & \multirow{2}{*}{$\begin{array}{c}\text { Akaider } \\
{[20]} \\
1996-1997\end{array}$} & \multirow{2}{*}{$\begin{array}{c}\text { Russiefeh } \\
\text { [20] } \\
1996\end{array}$} & \multirow{2}{*}{$\begin{array}{c}\begin{array}{c}\text { Malysia } \\
\text { Active } \\
\text { controlled } \\
\text { Landfill [21] }\end{array} \\
2007-2008\end{array}$} \\
\hline & Mean $\pm s d$ & Range & Mean $\pm s d$ & Range & Mean $\pm s d$ & Range & & & \\
\hline $\mathrm{pH}$ & $7.45 \pm 0.89$ & $6.71-8.77$ & $8.40 \pm 0.16$ & $8.14-8.66$ & $8.52 \pm 0.25$ & $8.01-8.79$ & 7.4 & 6.89 & 5.26 \\
\hline $\begin{array}{l}\text { Conductivity } \\
(\mathrm{mS} / \mathrm{cm})\end{array}$ & $87 \pm 21$ & $50-106$ & $86 \pm 33$ & $42-136$ & $35 \pm 4$ & $30-39$ & 5.3 & 200 & NA \\
\hline $\mathrm{COD}(\mathrm{mg} / \mathrm{L})$ & $\begin{array}{c}216,281 \pm \\
159,626\end{array}$ & $\begin{array}{l}13,000- \\
500,000\end{array}$ & $\begin{array}{c}64,109 \pm \\
42,386\end{array}$ & $\begin{array}{l}24,000- \\
135,000\end{array}$ & $4000 \pm 826$ & $3000-5000$ & 1237 & 229,932 & $\begin{array}{c}12,470- \\
80,600\end{array}$ \\
\hline $\mathrm{TOC}(\mathrm{mg} / \mathrm{L})$ & $16,000 \pm 7736$ & $3500-21,000$ & $14,286 \pm 6454$ & $6000-21,000$ & $959 \pm 504$ & $500-2,000$ & 168 & 3592 & $6296-24,322$ \\
\hline TOC/COD & $0.12 \pm 0.08$ & $0.04-0.27$ & $0.25 \pm 0.08$ & $0.15-0.40$ & $0.24 \pm 0.09$ & $0.14-0.40$ & & & \\
\hline $\mathrm{Cr}(\mathrm{mg} / \mathrm{L})$ & $6.92 \pm 5.89$ & $0-15.91$ & $6.88 \pm 7.01$ & $1.51-20.50$ & $1.27 \pm 0.49$ & $0.66-2.04$ & $<0.10$ & 0.87 & $0-5.0$ \\
\hline $\mathrm{Mn}(\mathrm{mg} / \mathrm{L})$ & $3.46 \pm 3.89$ & $0-10.37$ & $1.11 \pm 1.61$ & $0-3.97$ & $0.36 \pm 0.14$ & $0-0.41$ & 0.06 & 33.6 & $10.56-38.17$ \\
\hline $\mathrm{Cd}(\mathrm{mg} / \mathrm{L})$ & $0.67 \pm 1.25$ & $0-3.96$ & $1.23 \pm 1.82$ & $0-4.50$ & $0.40 \pm 0.16$ & $0-0.48$ & $<0.05$ & $<0.05$ & $0-0.042$ \\
\hline $\mathrm{Ni}(\mathrm{mg} / \mathrm{L})$ & $2.53 \pm 1.42$ & $0.54-4.28$ & $2.88 \pm 1.95$ & $0.74-6.69$ & $0.24 \pm 0.42$ & $0-1.06$ & $<1.00$ & 3.68 & $0.105-1.847$ \\
\hline $\mathrm{Cu}(\mathrm{mg} / \mathrm{L})$ & $1.1 \pm 1.4$ & $0.31-4.85$ & $2.9 \pm 2.2$ & $0.28-6.29$ & $0.5 \pm 0.4$ & $0.2-1.4$ & $<0.05$ & 0.11 & $0-1.597$ \\
\hline As $(\mu \mathrm{g} / \mathrm{L})$ & $141 \pm 93$ & $54-313$ & $92 \pm 61$ & $30-202$ & $11 \pm 7$ & $5-21$ & NA & NA & NA \\
\hline
\end{tabular}

decomposition that has taken place and physical modifycation or shredding of the waste [22,25].

\section{2. $\mathrm{pH}$ and Conductivity}

$\mathrm{pH}$ increases with the age of the landfill. It has been reported that new landfills have $\mathrm{pH}$ values between 4.5 7.5. For old mature landfills, $\mathrm{pH}$ usually increases up to 9 $[22,27]$. The average $\mathrm{pH}$ values for leachate at Ghabawi, Akaider and Russiefeh were 7.45, 8.40, and 8.52, respectively. Both Ghabawi and Akaider landfills are in the acetic phase which is reported to have high concentrations of Volatile Fatty Acids (VFAs) as well as high COD [28]. This will cause the $\mathrm{pH}$ to be lower than that for the aged closed landfill of Russiefeh where the $\mathrm{pH}$ of leachate will increase due to the consumption of VFAs in the methanogenic phase.

EC values were found to be ranging between 30 to 136 $\mathrm{mS} / \mathrm{cm}$ with high fluctuation from one month to another (high standard deviation). These values are comparable to what is reported in literature for municipal landfill leachates [11]. The active sites (Ghabawi and Akaider) exhibit high EC measurements since they are expected to contain very high concentration of salt ions. The oldclosed site of Russiefeh shows less EC compared to the active sites.

\subsection{Heavy Metals}

The concentration of heavy metals in landfill leachate is an important parameter in selecting a leachate treatment method [29]. Metals can take different forms in the leachate depending on $\mathrm{pH}$, degradation phase and complexation of waste matrix [30]. The presence of large concentrations of heavy metals will retard the stability of the solid waste degradation process [31].

In our analysis, we measured the following heavy metals in leachates: $\mathrm{Ni}, \mathrm{Co}, \mathrm{Cr}, \mathrm{Zn}, \mathrm{Pb}, \mathrm{Mn}, \mathrm{Al}, \mathrm{Cd}, \mathrm{Cu}$ and As, which are considered of highest concern in American and European communities. Mercury was also measured in the initial trials of this study but no concentration was evaluated in all three landfill. Analysis results are compared to Jordanian standards for the maximum allowable discharge limit of industrial wastewater (JIEC), and also to the limits set by US Environmental Protection Agency (USEPA) for groundwater protection performance standards [25].

The measurements showed significant fluctuation of concentrations from month to month especially for the active landfills. This is due to variation in the composition of dumped waste as well as environmental and weather conditions. In general, the concentrations of heavy metals were highest in the months of December and January, especially in the active landfills of Ghabawi and Akaider. These two months are considered the beginning of the wet season in Jordan, which resulted in considerable leachate generation compared to the dry season [32]. The $\mathrm{Co}, \mathrm{Zn}, \mathrm{Pb}$ and $\mathrm{Al}$ in the three landfills' leachates exhibit no significant threat. However, the concentrations of $\mathrm{Cr}, \mathrm{Mn}$, and $\mathrm{Cd}$ were high in all the sites exceeding both JIEC and EPA limits, as shown in Figures 4(a)-(c). Furthermore, Ghabawi and Akaider 
sites showed very high and comparable concentrations of $\mathrm{Ni}$ and As (Figures 4(d) and (e)).

The effect of active versus closed landfills on heavy metals concentrations can be shown by comparing the values estimated from this study to that reported by Stuart and Klinck [20]. The mean values for $\mathrm{Cr}, \mathrm{Cd}, \mathrm{Cu}, \mathrm{Mn}$, and $\mathrm{Ni}$ concentrations increased significantly in the active Akaider landfill since 1996 as shown in Table 2. On the other hand, Russiefeh site showed a slight increase in $\mathrm{Cr}, \mathrm{Cd}$ and $\mathrm{Cu}$ concentrations and a considerable decrease in $\mathrm{Mn}$ and Ni concentrations with time. The synergetic behaviour of $\mathrm{Ni}$ and $\mathrm{Mn}$ can be related to the unregulated disposal of old batteries, the main sources of these two metals, which are not collected separately in Jordan.

A study on tap water quality in four different Jordanian cities (Amman, Zarqa, Jerash and Karak) reported that all cities have very high $\mathrm{Ni}$ concentration in the range of $1117 \mu \mathrm{g} / \mathrm{L}$ to $445 \mu \mathrm{g} / \mathrm{L}$ [33]. This indicates that the groundwater resources have already been affected by migration of heavy metals from uncontrolled landfill leachates to groundwater resources. For $\mathrm{Cu}$, only Akaider landfill has a high concentration of $\mathrm{Cu}$ exceeding the limit of $2.0 \mathrm{mg} / \mathrm{L}$, as shown in Figure 4(f).

Comparison of the Jordanian active-controlled landfill (Ghabawi) to a similar landfill in Malaysia [21] shows that, except for Mn, all other heavy metals have much higher concentrations in Jordan leachate than in Malaysia, as shown in Table 2. This could be due to better solid waste segregation and management in Malaysia compared to Jordan and of legislation regulating waste disposal, segregation and recycling. Moreover, Malaysia is known to have higher rainfall rates than Jordan, which dilute the leachate.

Pollution of heavy metals may arise from different sources. $\mathrm{Cd}, \mathrm{Cr}, \mathrm{Mn}$ and $\mathrm{Ni}$ are mainly introduced to the environment from electroplating, spent rechargeable and household batteries [34-36] and the tannery industry [6]. Contamination with inorganic As comes from uncontrolled disposal of electronic wastes [37] present in circuit boards, computer chips and LCD displays. Fertilizers were also reported as a source for As contamination [38,39]. Ponthieu et al. [40] studied the speciation of arsenic in landfill leachates. Their results showed that As is present in the leachate in both organic and the toxic inorganic (AsIII and AsV) forms.

For the investigated landfills, the influence of age on leachate organic contents (estimated by COD and TOC) was clear, where newly active landfill (Ghabawi) had the highest COD and TOC concentrations and the lowest was for the old-closed (Russiefeh) landfill. However, there was no clear trend of leachate age with respect to heavy metals concentration.

\subsection{Leachate Treatment}

Leachate treatment is different from wastewater treatment due to the relatively small flow rates and the complex leachate composition [23]. The selection of leachate treatment technology will depend on the main parameters of leachate, such as $\mathrm{COD}, \mathrm{BOD}_{5}, \mathrm{TOC}$ and heavy metals. Normally a combination of different treatment methods are used to meet the limit values for the discharge of treated leachate. Unfortunately, no limits for the discharged leachate are yet regulated in Jordan. Therefore, the limits set by developed countries, such as Germany, will be used as guidance in the selection process (Table 3). The current study showed considerable fluctuation in leachate characteristics due to climate conditions, waste composition, bacterial activity, and landfill age. The oldclosed site of Russiefeh shows low EC compared to other sites, but the measured value indicates that salts are still a problem to be addressed for its leachate.

Although the values of COD and TOC became lower with the age of old-closed Russiefeh landfill, the stabilized leachate still shows high strength of COD and TOC. These values can be explained by the presence of not easily degradable organics, such as humic and fulvic acids. This landfill is in the stable methanogenic phase where biological treatment will not be effective. For such a landfill, adsorption by activated carbon or reverse osmosis are suggested as potential treatment methods to

Table 3. Limit values for the discharge of treated leachate according to German standards (51. Anhang Rahmen-AbwasserVwV, [41]).

\begin{tabular}{cc}
\hline Parameter & $\begin{array}{c}\text { Limiting Concentration } \\
(\mathbf{m g} / \mathbf{L})\end{array}$ \\
\hline COD & 200 \\
BOD5 & 20 \\
Nitrogen, total & 70 \\
(Sum $\left.\mathrm{NH}_{4}+\mathrm{NO}_{2}+\mathrm{NO}_{3}\right)$ & 3 \\
Phosphorus, total & 10 \\
Hydrocarbons & 2 \\
Nitrite-Nitrogen & 0.05 \\
Mercury & 0.1 \\
Cadmium & 0.5 \\
Chromium & 0.1 \\
Chromium (VI) & 1 \\
Nickel & 0.5 \\
Lead & 0.5 \\
Copper & 2 \\
Zinc & 0.2 \\
\hline Cyanide, easy liberatable & \\
\hline
\end{tabular}


reduce COD and heavy metals values below the limits [23]. For the two active sites of Ghabawi and Akaider biological treatment (anaerobic) will be an effective method to reduce biodegradable organics. However, further physical-chemical treatments, such as chemical oxidation, adsorption or reverse osmosis, are recommended to meet the standards [23].

\section{Conclusion}

The results of this study show that leachates from landfills possess high contamination potential to the limited water sources in Jordan. The concentrations of organic contents were inversely proportional to the available degradation period. Heavy metals were found to exceed the allowable limits in Jordan for industrial wastewater discharge for the metals $\mathrm{Cr}, \mathrm{Mn}, \mathrm{Cd}, \mathrm{Ni}$ and As. These results emphasize the need for better solid waste management in Jordan including source separation of wastes and forcing the regulations on disposal of industrial and hazardous wastes.

\section{Acknowledgements}

The authors wish to thank the German-Jordanian University, the Higher Council for Science and Technology in Jordan, and the European Union presented by Support to Research and Technological Development \& Innovation Initiative \& Strategies in Jordan (SRTD) Project for their financial support to this project. Special thanks to Greater Amman Municipality and Irbid Common Services Council for their cooperation in providing the leachates samples.

\section{REFERENCES}

[1] D. Kumar and B. J. Alappat, "Analysis of Leachate Pollution Index and Formulation of Sub-Leachate Pollution Indices," Waste Management and Research, Vol. 22, No. 3, 2005, pp. 230-239. doi:10.1177/0734242X05054875

[2] P. Kjeldsen and M. Christophersen, "Composition of Leachate from Old Landfills in Denemark," Waste Management and Research, Vol. 19, No. 3, 2001, pp. 249-256. doi:10.1177/0734242X0101900306

[3] H. A. Qdais, "Selection of Landfill Leachate Management Strategy Using Decision Support System," The Journal of Solid Waste Technology and Management, Vol. 36, No. 4, 2010, pp. 246-257. doi:10.5276/JSWTM.2010.246

[4] R. M. Borden and T. M. Yanoschak, "Ground and Surface Water Quality Impacts of North Carolina Sanitary Landfills," Journal of the American Water Resources Association, Vol. 26, No. 2, 1990, pp. 269-277. doi:10.1111/j.1752-1688.1990.tb01370.x

[5] H. Khattabi, L. Aleya and J. Mania, "Changes in the Quality of Landfill Leachates from Recent and Aged Mu- nicipal Solid Waste," Waste Management and Research, Vol. 20, No. 4, 2002, pp. 357-364. doi:10.1177/0734247X0202000407

[6] Z. Gotvajn, T. Tisler and J. Zagorc-Koncan, "Comparison of Different Treatment Strategies for Industrial Landfill Leachate," Journal of Hazardous Materials, Vol. 162, No. 2-3, 2009, pp. 1446-1456. doi:10.1016/j.jhazmat.2008.06.037

[7] A. J. Lee and G. F. Lee, "Groundwater Pollution by Municipal Landfills: Leachate Composition, Detection and Water Quality Significance," Proceedings of the 4th, International Symposium, Margherita Di Pula, 11-15 October, 1993, pp. 1093-1103.

[8] Y. H. Abu-Rukah and A. S. El-Aloosy, "Various Variables Migration in Landfill Site Using Statistical Explanation. A Case Study El-Akader Landfill Site, North Jordan," Journal of Institute of Mathematics and Computer Sciences, Vol. 10, No. 2, 1997, pp. 113-130.

[9] P. Kjeldsen, M. Barlaz, A. Rooker, A. Baun, A. Ledin and T. Christensen, "Present and Long Term Composition of MSW Landfill Leachate: A Review," Critical Reviews in Environmental Science and Technology, Vol. 32, No. 4, 2002, pp. 297-336. doi:10.1080/10643380290813462

[10] S. Renou, J. G. Givaudan, S. Poulain, F. Dirassouyan and P. Moulin, "Landfill Leachate Treatment: Review and Opportunity," Journal of Hazardous Materials, Vol. 150, No. 3, 2008, pp. 468-493. doi:10.1016/j.jhazmat.2007.09.077

[11] L. Ziyang, Z. Youcai, Y. Tao, S. Yu, C. Huili, Z. Nanwen and H. Renhua, "Natural Attenuation and Characterization of Contaminants Composition in Landfill Leachate under Different Disposing Ages," Science of the Total Environment, Vol. 407, No. 10, 2009, pp. 3385-3391. doi:10.1016/j.scitotenv.2009.01.028

[12] V. Gounaris, P. R. Anderson and T. M. Holsen, "Characteristics and Environmental Significance of Colloids in Landfill Leachate," Environmental Science \& Technology, Vol. 27, No. 7, 1993, pp. 1381-1387. doi:10.1021/es00044a013

[13] A. F. Al Yaqout and M. F. Hamoda, "Evaluation of Landfill Leachate in Arid Climate-A Case Study," Environment International, Vol. 29, No. 5, 2003, pp. 593600. doi:10.1016/S0160-4120(03)00018-7

[14] D. Kulikowska and E. Klimiuk, "The Effect of Landfill Age on Leachate Composition," Bioresource Technology, Vol. 99, No. 13, 2008, pp. 5981-5985. doi:10.1016/j.biortech.2007.10.015

[15] T. H. Christensen, P. Kjeldsen, P. L. Bjerg, D. L. Jensen, J. B. Christensen, A. Baun, H.-J. Albrechsten and G. Heron, "Biogeochemistry of Landfill Leachate Plumes," Applied Geochemistry, Vol. 16, No. 7-8, 2001, pp. 659718. doi:10.1016/S0883-2927(00)00082-2

[16] Y. Abu-Rukah and O. Al-Kofahi, "The Assessment of the Effect of Landfill Leachate on Ground-Water Quality-A Case Study. El-Akader Landfill Site-North Jordan," Journal of Arid Environments, Vol. 49, No. 3, 2001, pp. 615 630. doi:10.1006/jare.2001.0796

[17] Z. Tadros, "Site Selection and Management of Solid 
Wastes Disposal Site. Case Study, Ghabawi Landfill/ Jordan," Proceedings Sardinia 2007, Eleventh International Waste Management and Landfill Symposium, Cagliari, 1-5 October 2007.

[18] B. Mrayyan and M. Hamdi, "Management Approaches to Integrated Solid Waste in Industrialized Zones in Jordan: A Case of Zarqa City," Waste Management, Vol. 26, No. 2, 2006, pp. 195-205. doi:10.1016/j.wasman.2005.06.008

[19] BGR and WAJ "The North Jordan Resources Investigation Project. Amman Zarqa Basin Water Resources Study," Water Authority of Jordan (WAJ), The Federal Institute for Geosciences and Natural Resources in Germany (BGR), Amman, 1989.

[20] M. E. Stuart and B. A. Klinck, "A Catalogue of Leachate Quality for Selected Landfills from Newly Industrialised Countries," British Geological Survey Technical Report WC/98/49, Keyworth, 1998.

[21] N. Yusof, A. Haraguchi, M. A. Hassan, M. R. Othman, M. Wakisaka and Y. Shirai, "Measuring Organic Carbon, Nutrients and Heavy Metals in Rivers Receiving Leachate from Controlled and Uncontrolled Municipal Solid Waste (MSW) Landfills," Waste Management, Vol. 29, No. 10, 2009, pp. 2666-2680. doi:10.1016/j.wasman.2009.05.022

[22] S. Aziz, H. Abdul Aziz, M. Yusoff, M. Bashir and M. Umar, "Leachate Characterization in Semi-Aerobic and Anaerobic Sanitary Landfills: A Comparative Study," Journal of Environmental Management, Vol. 91, No. 12, 2010, pp. 2608-2614. doi:10.1016/j.jenvman.2010.07.042

[23] R. Stegmann, K.-U. Heyer and R. Cossu, "Leachate Treatment," Proceedings Sardinia 2005, Tenth International Waste Management and Landfill Symposium, Cagliari, 37 October 2005.

[24] H. J. Ehrig, "Water and Element Balances of Landfills," In: Lecture Notes in Earth Sciences: The Landfill, 1989.

[25] EPA Report, "Decision Maker's Guide to Solid Waste Management," Volume II, EPA 530-R-95-023, 1995.

[26] K. Kylefors, "Landfill Leachate Management-Short and Long Term Perspectives," Lulea University of Technology, Luleå, 1997, p. 16.

[27] G. Tchobanoglous, H. Theisen and S. Vigil, "Integral Solid Waste Management Engineering Principles and Management Issues," 1st Edition, Irwin/McGraw-Hill, New York, 1993.

[28] G. J. Farquhar, "Leachate: Production and Characterization," Canadian Journal of Civil Engineering, Vol. 16, No. 3, 1989, pp. 317-325. doi:10.1139/189-057

[29] T. Tolaymat, F. Kremer, D. Carson and W. Davis-Hoover, "Monitoring Approaches for Landfill Bioreactors," National Risk Management Research Laboratory, Office of Research and Development, Cincinnati, 2004.

[30] F. Pohland, W. Cross, J. Gloud and D. Reinhart, "Behavior and Assimilation of Organic and Inorganic Priority Pollutants Co-Disposed with Municipal Refuse," Risk
Reduction Engineering Laboratory, Office of Research and Development, Cincinnati, 1993.

[31] F. Pohland and S. Harper, "Retrospective Evaluation of the Effects of Selected Industrial Wastes on Municipal Solid Waste Stabilization in Simulated Landfills," Hazardous Waste Engineering Research Laboratory, Office of Research and Development, Cincinnati, 1986.

[32] I. M. Rafizul and M. Alamgir, "Characterization and Tropical Seasonal Variation of Leachate: Results from Landfill Lysimeter Studied," Waste Management, Vol. 32, No. 11, 2012, pp. 2080-2095. doi:10.1016/j.wasman.2012.01.020

[33] M. Batarseh, "The Quality of Potable Water Types in Jordan," Environmental Monitoring and Assessment, Vol. 117, No. 1-3, 2006, pp. 235-244. doi:10.1007/s10661-006-0992-x

[34] S. Xará, J. Delgado, M. Almeida and C. Costa, "Laboratory Study on the Leaching Potential of Spent Alkaline Batteries," Waste Management, Vol. 29, No. 7, 2009, pp. 2121-2131. doi:10.1016/i.wasman.2009.03.010

[35] S. Karnchanawong and P. Limpiteeprakan, "Evaluation of Heavy Metal Leaching from Spent Household Batteries Disposed in Municipal Solid Waste," Waste Management, Vol. 29, No. 2, 2009, pp. 550-558. doi:10.1016/j.wasman.2008.03.018

[36] C. Rydh and B. Svard, "Impact on Global Metal Flows Arising from the Use of Portable Rechargeable Batteries," The Science of the Total Environment, Vol. 302, No. 1-3, 2003, pp. 167-184. doi:10.1016/S0048-9697(02)00293-0

[37] T. Wagner, "Shared Responsibility for Managing Electronic Waste: A Case Study of Maine, USA," Waste Management, Vol. 29, No. 12, 2009, pp. 3014-3021. doi:10.1016/j.wasman.2009.06.015

[38] S. Macedo, R. de Jesus, K. Garcia, V. Hatje, A. Queiroz and S. Ferreira, "Determination of Total Arsenic and Arsenic (III) in Phosphate Fertilizers and Phosphate Rocks by HG-AAS after Multivariate Optimization Based on Box-Behnken Design," Talanta, Vol. 80, No. 2, 2009, pp. 974-979. doi:10.1016/j.talanta.2009.08.025

[39] N. Mirlean and A. Roisenberg, "The Effect of Emissions of Fertilizer Production on the Environment Contamination by Cadmium and Arsenic in Southern Brazil," Environmental Pollution, Vol. 143, No. 2, 2006, pp. 335-340. doi:10.1016/i.envpol.2005.11.022

[40] M. Ponthieu, P. Pinel-Raffaitin, I. Le Hecho, L. Mazeas, D. Amouroux, O. Donard and M. Potin-Gautier, "Speciation Analysis of Arsenic in Landfill Leachate," Water Research, Vol. 41, No. 14, 2007, pp. 3177-3185. doi:10.1016/j.watres.2007.04.026

[41] ANONYMUS, "Anhang 51: Oberirdische Ablagerung von Abfällen. Allgemeine Rahmen-Verwaltungsvorschrift über Mindestanforderungen an das Einleiten von Abwasser in Gewässer,” German Regulation, 1996. 